\title{
PEMEROLEHAN BAHASA PERTAMA SEBAGAI DASAR \\ PEMBELAJARAN BAHASA KEDUA \\ (Kajian Psikolinguistik)
}

\author{
Alam Budi Kusuma \\ Keahlian Pendidikan Bahasa Arab \\ Dosen pada Program Studi Pendidikan Bahasa Arab STAIMS \\ Yogyakarta \\ Alamat e-mail : alambudi.kusuma@yahoo.com
}

\begin{abstract}
ABSTRAK
Artikel ini bertujuan untuk memaparkan proses perkembangan bahasa. Upaya yang dilakukan para Linguis dan Psikolog dalam mengkaji permasalahan pembelajaran bahasa dari berbagai sudut pandang dan teori merupakan hal yang banyak manfaatnya bagi perkembangan bahasa sehingga pada saat ini kita bisa menikmati hasil kajian tentang bahasa yang lebih kita kenal dengan psikolinguistik. Terdapat dua proses yang terjadi ketika seseorang memperoleh bahasa pertamanya, yaitu proses kompetensi dan proses performansi. Kedua proses ini merupakan proses yang berlainan, kompetensi adalah proses penguasaan tata bahasa (fonologi, morfologi, sintaksis, dan semantik) secara tidak disadari. Hal yang patut dipertanyakan adalah bagaimana strategi si anak dalam memperoleh bahasa pertamanya dan apakah setiap anak memiliki strategi yang sama dalam memperoleh bahasa pertamanya?
\end{abstract}

Kata kunci : belajar bahasa, vokal, proses pembelajaran, teori belajar

\section{ABSTRACT}

This article aims to describe the process of language development. Efforts made the linguist and psychologist in studying the problems of language learning from a variety of viewpoints and the theory is that a lot of benefits for language development so that today we can enjoy the results of studies on the language more familiar with psycholinguistics. There are two processes that occur when a person obtains his first language, which is a process of competence and performance process. These processes are different processes, competence is the process of mastery of grammar (phonology, 
morphology, syntax and semantics) unconsciously. It needs to be questioned is how the strategy of the child in gaining his first language and whether each child has the same strategy in gaining his first language?

\section{Keywords: learning a language, vocal, learning, learning theory}

\section{A. Pendahuluan}

Mempelajari bahasa merupakan suatu aktivitas yang sangat panjang dan kompleks dan bukanlah serangkaian langkah mudah yang bisa diamati atau diprogram dalam sebuah panduan ringkas. Apapun yang manusia lakukan sewaktu berkumpul dengan temannya dalam berbagai aktivitas seperti bermain, bertengkar, dan aktivitas lainnya manusia tidak lepas dari aktivitas bertutur kata. Kemampuan bahasa inilah yang membedakan manusia dengan makhluk lainnya, seringkali kita mendengar ungkapan bahwa manusia adalah speaking animal (hewan yang berbicara).

Upaya yang dilakukan para Linguis dan Psikolog dalam mengkaji permasalahan pembelajaran bahasa dari berbagai sudut pandang dan teori merupakan hal yang banyak manfaatnya bagi perkembangan bahasa sehingga pada saat ini kita bisa menikmati hasil kajian tentang bahasa yang lebih kita kenal dengan psikolinguistik.. disiplin psikolinguistik sangat erat kaitannya dengan pemerolehan bahasa, pembelajaran bahasa, dan penggunaan bahasa oleh manusia.

Pada dasarnya manusia adalah makhluk yang unik dengan sendirinya, manusia sebagai pengguna bahasa dianggap sebagai organisme yang melakukan aktivitas untuk mencapai ranah psikologi, baik kognitif, afektif, maupun psikomotorik. Kemampuan dalam pemerolehan bahasa baik 
secara reseptif (kemampuan menyimak dan membaca) ataupan produktif (kemampuan berbicara dan menulis) tentunya melibatkan ketiga ranah tersebut. Pada dasarnya kemampuan pemerolehan bahasa sangat berkaitan erat antara kemampuan yang satu dengan kemampuan yang lainnya yaitu antara reseptif dan produktif.

Pada artikel yang penulis tulis ini, ruang lingkup kajiannya akan membahas tentang pemerolehan bahasa pertama (BI) sebagai dasar pembelajaran bahasa kedua (BII). Penulis lebih memfokuskan dalam beberapa hal saja, yaitu: teori-teori pemerolehan bahasa, bagaimana proses pemerolehan bahasa pertama dan bahasa kedua, dan juga bagaimana hubungan pemerolehan BI sebagai dasar pembelajaran BII.

\section{B. Pemerolehan Bahasa Pertama atau Bahasa Ibu}

Pemerolehan bahasa merupakan proses yang berlangsung di dalam otak kanak-kanak mulai dari ketika dia memperoleh bahasa pertamanya atau bahasa ibunya. Pemerolehan bahasa biasanya dibedakan dari pembelajaran bahasa ( language learning). Pembelajaran bahasa berkaitan dengan proses-proses yang terjadi pada waktu seorang kanakkanak mempelajari bahasa kedua, setelah dia memperoleh bahasa pertamanya. Jadi pemerolehan bahasa berkenaan dengan bahasa pertama, sedangkan pembelajaran bahasa berkenaan dengan bahasa kedua. Namun banyak juga yang menggunakan istilah pemerolehan bahasa untuk bahasa kedua. ${ }^{1}$

${ }^{1}$ Abdul Chaer, Psikolinguistik:Kajian Teoretik, (Jakarta: Rineka Cipta, 2003), hal. 167. 
Alam Budi Kusuma : Pemerolehan Bahasa Pertama

Penguasaan bahasa pertama diperoleh secara ilmiah, secara tidak sadar di dalam lingkungan keluarga anak-anak tersebut. 2 Setiap anak di dalam lingkungan pertumbuhan normal, memperoleh bahasa asli mereka dengan lancar dan efisien, lebih jauh, mereka menguasainya secara alami tanpa pendidikan khusus sekalipun bukannya tanpa upaya dan perhatian yang memadai pada bahasa. ${ }^{3}$

Terdapat dua proses yang terjadi ketika seseorang memperoleh bahasa pertamanya, yaitu proses kompetensi dan proses performansi. Kedua proses ini merupakan proses yang berlainan, kompetensi adalah proses penguasaan tata bahasa (fonologi, morfologi, sintaksis, dan semantik) secara tidak disadari. Kompetensi ini dibawa oleh setiap anak sejak lahir, meskipun dibawa sejak lahir, kompetensi memerlukan pembinaan sehingga anak-anak memiliki performansi dalam bahasa. Performansi adalah kemampuan anak menggunakan bahasa untuk berkomunikasi. Performansi terdiri dari dua proses, yaitu proses pemahaman dan proses penerbitan kalimat-kalimat. Proses pemahaman melibatkan kemampuan mengamati dan mempersepsi kalimat-kalimat yang didengar, sedangkan proses penerbitan melibatkan kemampuan menghasilkan kalimat-kalimat sendiri. ${ }^{4}$

Selanjutnya, Chomsky juga beranggapan bahwa pemakai bahasa mengerti struktur dari bahasanya yang membuat dia dapat mengkreasi kalimat-kalimat baru yang tidak terhitung jumlahnya dan membuat dia mengerti kalimat-kalimat

\footnotetext{
2 Iskandarwassid dkk, Strategi Pembelajaran Bahasa Asing (Bandung: PT Remaja Rosdakarya, 2008), hal.77.

${ }^{3}$ Douglas Brown, Prinsip Pembelajaran dan Pengajaran bahasa (Jakarta: Kedubes Amerika Serikat, 2007), hal. 26.

4 Abdul Chaer, Psikolinguistik............. (Jakarta: Rineka Cipta, 2003) hal. 167.
} 
tersebut. Jadi, kompetensi adalah pengetahuan intuitif yang dimiliki seorang individu mengenai bahasa ibunya (native languange). Intuisi linguistik ini tidak begitu saja ada, tetapi dikembangkan pada anak sejalan dengan pertumbuhannya, sedangkan performansi adalah sesuatu yang dihasilkan oleh kompetensi.

Hal yang patut dipertanyakan adalah bagaimana strategi si anak dalam memperoleh bahasa pertamanya dan apakah setiap anak memiliki strategi yang sama dalam memperoleh bahasa pertamanya? Berkaitan dengan hal ini, Dardjowidjojo, menyebutkan bahwa pada umumnya kebanyakan ahli kini berpandangan bahwa anak di mana pun juga memperoleh bahasa pertamanya dengan memakai strategi yang sama.

Kesamaan ini tidak hanya dilandasi oleh biologi dan neurologi manusia yang sama, tetapi juga oleh pandangan mentalistik yang menyatakan bahwa anak telah dibekali dengan bekal kodrati pada saat dilahirkan. ${ }^{5}$ Di samping itu, dalam bahasa juga terdapat konsep universal sehingga anak secara mental telah mengetahui kodrat-kodrat yang universal ini. Chomsky mengibaratkan anak sebagai entitas yang seluruh tubuhnya telah dipasang tombol serta kabel listrik: mana yang dipencet, itulah yang akan menyebabkan bola lampu tertentu menyala. Jadi, bahasa mana dan wujudnya seperti apa ditentukan oleh input sekitarnya.

\section{Proses Pemerolehan Bahasa Pertama}

Perlu untuk diketahui adalah seorang anak tidak dengan tiba-tiba memiliki tata bahasa B1 dalam otaknya dan lengkap dengan semua kaidahnya. B1 diperolehnya dalam beberapa

5 Soenjono Dardjowidjojo, Psikolinguistik: Pengantar Pemahaman Bahasa Manusia (Jakarta: Yayasan Obor, 2005), hal. 243-244. 
tahap dan setiap tahap berikutnya lebih mendekati tata bahasa dari bahasa orang dewasa. Menurut para ahli, tahaptahap ini sedikit banyaknya ada ciri kesemestaan dalam berbagai bahasa di dunia.

Pengetahuan mengenai pemerolehan bahasa dan tahapnya yang paling pertama di dapat dari buku-buku harian yang disimpan oleh orang tua yang juga peneliti ilmu psikolinguistik. Dalam studi-studi yang lebih mutakhir, pengetahuan ini diperoleh melalui rekaman-rekaman dalam pita rekaman, rekaman video, dan eksperimen-eksperimen yang direncanakan. Ada sementara ahli bahasa yang membagi tahap pemerolehan bahasa ke dalam tahap pralinguistik dan linguistik. Akan tetapi, pendirian ini disanggah oleh banyak orang yang berkata bahwa tahap pralinguistik itu tidak dapat dianggap bahasa yang permulaan karena bunyi-bunyi seperti tangisan dan rengekan dikendalikan oleh rangsangan (stimulus) semata-mata, yaitu respons otomatis anak pada rangsangan lapar, sakit, keinginan untuk digendong, dan perasaan senang. Oleh karena itu, tahap-tahap pemerolehan bahasa yang dibahas dalam makalah ini adalah tahap linguistik yang terdiri atas beberapa tahap, yaitu (1) tahap pengocehan (babbling); (2) tahap satu kata (holofrastis); (3) tahap dua kata; (4) tahap menyerupai telegram (telegraphic speech).

\section{Vokalisasi Bunyi}

Pada umur sekitar 6 minggu, bayi mulai mengeluarkan bunyi-bunyi dalam bentuk teriakan, rengekan, dekur. Bunyi yang dikeluarkan oleh bayi mirip dengan bunyi konsonan atau vokal. Akan tetapi, bunyibunyi ini belum dapat dipastikan bentuknya karena 
memang belum terdengar dengan jelas. Yang menjadi pertanyaan adalah apakah bunyi-bunyi yang dihasilkan tadi merupakan bahasa? Fromkin dan Rodman menyebutkan bahwa bunyi tersebut tidak dapat dianggap sebagai bahasa. Sebagian ahli menyebutkan bahwa bunyi yang dihasilkan oleh bayi ini adalah bunyi-bunyi prabahasa/dekur/vokalisasi bahasa/tahap cooing. 6

Setelah tahap vokalisasi, bayi mulai mengoceh (babling). Celoteh merupakan ujaran yang memiliki suku kata tunggal seperti mu dan da. Adapun umur si bayi mengoceh tak dapat ditentukan dengan pasti. Mar'at menyebutkan bahwa tahap ocehan ini terjadi pada usia antara 5 dan 6 bulan. ${ }^{7}$ Dardjowidjojo menyebutkan bahwa tahap celoteh terjadi sekitar umur 6 bulan. Tidak hanya itu. ada juga sebagian ahli menyebutkan bahwa celoteh terjadi pada umur 8 sampai dengan 10 bulan. Perbedaan pendapat seperti ini dapat saja. Yang perlu diingat bahwa kemampuan anak berceloteh tergantung pada perkembangan neurologi seorang anak. ${ }^{8}$

Begitu anak melewati periode mengoceh, mereka mulai menguasai segmen-segmen fonetik yang merupakan balok bangunan yang dipergunakan untuk mengucapkan perkataan. Mereka belajar bagaimana mengucapkan sequence of segmen, yaitu silabe-silabe dan kata-kata. Cara anak-anak mencoba menguasai segmen fonetik ini adalah dengan menggunakan teori hypothesis-testing. Menurut

6 Fromkin Victoria dan Robert Rodman.. An Introduction to Language (Florida: Harcourt Brace Jovanovich Collage, 1993), hal. 395.

7 Samsunuwiyati Mar'at, Psikolinguistik Suatu Pengantar (Bandung: PT Refika Aditama, 2005), hal.43.

8Soenjono Dardjowidjojo, Psikolinguistik.... hal.244. 
teori ini anak-anak menguji coba berbagai hipotesis tentang bagaimana mencoba memproduksi bunyi yang benar.

Apakah tahap celoteh ini penting bagi si anak. Jawabannya tentu saja penting. Tahap celoteh ini penting artinya karena anak mulai belajar menggunakan bunyibunyi ujaran yang benar dan membuang bunyi ujaran yang salah. Dalam tahap ini anak mulai menirukan pola-pola intonasi kalimat yang diucapkan oleh orang dewasa.

2. Tahap Satu-Kata atau Holofrastis

Tahap ini berlangsung ketika anak berusia antara 12 dan 18 bulan. Ujaran-ujaran yang mengandung kata-kata tunggal diucapkan anak untuk mengacu pada benda-benda yang dijumpai sehari-hari. Pada tahap ini pula seorang anak mulai menggunakan serangkaian bunyi berulangulang untuk makna yang sama. pada usia ini pula, sang anak sudah mengerti bahwa bunyi ujar berkaitan dengan makna dan mulai mengucapkan kata-kata yang pertama.

Menurut pendapat beberapa peneliti bahasa anak, kata-kata dalam tahap ini mempunyai tiga fungsi, yaitu kata-kata itu dihubungkan dengan perilaku anak itu sendiri atau suatu keinginan untuk suatu perilaku, untuk mengungkapkan suatu perasaan, untuk memberi nama kepada suatu benda. Dalam bentuknya, kata-kata yang diucapkan itu terdiri dari konsonan-konsonan yang mudah dilafalkan seperti $m, p, s, k$ dan vokal-vokal seperti $a, i, u, e$.

3. Tahap Dua-Kata, Satu Frase

Tahap ini berlangsung ketika anak berusia 18-20 bulan. Ujaran-ujaran yang terdiri atas dua kata mulai muncul seperti mama mam dan papa ikut. Kalau pada tahap holofrastis ujaran yang diucapkan si anak belum 
tentu dapat ditentukan makna, pada tahap dua kata ini, ujaran si anak harus ditafsirkan sesuai dengan konteksnya. Pada tahap ini pula anak sudah mulai berpikir secara "subjek + predikat" meskipun hubungan-hubungan seperti infleksi, kata ganti orang dan jamak belum dapat digunakan. Dalam pikiran anak itu, subjek + predikat dapat terdiri atas kata benda + kata benda, seperti "Ani mainan" yang berarti "Ani sedang bermain dengan mainan" atau kata sifat + kata benda, seperti "kotor patu" yang artinya "Sepatu ini kotor" dan sebagainya.

4. Ujaran Telegrafis

Pada usia 2 dan 3 tahun, anak mulai menghasilkan ujaran kata-ganda (multiple-word utterances) atau disebut juga ujaran telegrafis. Anak juga sudah mampu membentuk kalimat dan mengurutkan bentuk-bentuk itu dengan benar. Kosakata anak berkembang dengan pesat mencapai beratus-ratus kata dan cara pengucapan katakata semakin mirip dengan bahasa orang dewasa.

Pada usia dini dan seterusnya, seorang anak belajar B1-nya secara bertahap dengan caranya sendiri. Ada teori yang mengatakan bahwa seorang anak dari usia dini belajar bahasa dengan cara menirukan. Namun, hasil peniruan yang dilakukan oleh si anak tidak akan sama seperti yang diinginkan oleh orang dewasa. Jika orang dewasa meminta sang anak untuk menyebutkan "He's going out", si anak akan melafalkan dengan "He go out". 9 Ada lagi teori yang mengatakan bahwa seorang anak belajar dengan cara penguatan (reinforcement), artinya kalau

9 Fromkin Victoria dan Robert Rodman.. An Introduction to Language........ hal. 403 
seorang anak belajar ujaran-ujaran yang benar, ia mendapat penguatan dalam bentuk pujian, misalnya bagus, pandai, dsb. Akan tetapi, jika ujaran-ujarannya salah, ia mendapat "penguatan negatif", misalnya lagi, salah, tidak baik. Pandangan ini berasumsi bahwa anak itu harus terus menerus diperbaiki bahasanya kalau salah dan dipuji jika ujarannya itu benar.

Teori ini tampaknya belum dapat diterima seratus persen oleh para ahli psikologi dan ahli psikolinguistik. Yang benar ialah seorang anak membentuk aturan-aturan dan menyusun tata bahasa sendiri. Tidak semua anak menunjukkan kemajuan-kemajuan yang sama meskipun semuanya menunjukkan kemajuan-kemajuan yang reguler.

\section{Proses Perkembangan Bahasa Anak}

Anak mengalami perkembangan bahasa secara bertahap. Tahapan perkembangan bahasa untuk anak dapat dipaparkan sebagai berikut :

1. Fonologi,

Fonologi adalah disiplin ilmu tentang perbendaharaan fonem sebuah bahasa dan distribusinya. Hal-hal yang dibahas dalam fonologi antara lain: 1) bunyi suara, 2) fonetik dan fonemik, 3) alat ucap, 4) pita suara, 5) vokal, 6) konsonan, 7) perubahan fonem, dan 8) intonasi. Dari bahasan-bahasan tersebut telaah fonologi fokus pada bunyi bahasa yang harus diperhatikan oleh penutur suatu bahasa.

Dalam pembelajaran bahasa ada prinsip-prinsip prioritas dalam penyampaian materi yaitu: 1) mengajarkan mendengarkan dan bercakap sebelum menulis, 2) mengakarkan kata sebelum kalimat, 3) menggunakan kata- 
kata yang lebih akrab dengan kehidupan sehari-hari. Dari ketiga prinsip itu fonologi berperan penting terhadap proses pemerolehan bahasa pertama pada anak.

Anak menggunakan bunyi-bunyi yang telah dipelajarinya dengan bunyi-bunyi yang belum dipelajari, misalnya menggantikan bunyi /1/ yang sudah dipelajari dengan bunyi / $\mathrm{r}$ / yang belum dipelajari. Pada akhir periode berceloteh, anak sudah mampu mengendalikan intonasi, modulasi nada, dan kontur bahasa yang dipelajarinya.

2. Morfologi

Morfologi adalah cabang linguistik yang mengidentifikasi satuan-satuan dasar bahasa sebagai satuan gramatikal. Morfologi mempelajari seluk-beluk bentuk kata serta pengaruh perubahan-perubahan bentuk kata terhadap golongan dan arti kata atau dengan kata lain dapat dikatakan bahwa morfologi mempelajari seluk beluk bentuk kata serta fungsi perubahan-perubahan bentuk kata itu baik fungsi gramatikal maupun fungsi semantik.

Pada usia tiga tahun anak sudah membentuk beberapa morfem yang menunjukkan fungsi gramatikal nomina dan verba yang digunakan. Kesalahan gramatika sering terjadi pada tahap ini karena anak masih berusaha mengatakan apa yang ingin dia sampaikan. Anak terus memperbaiki bahasanya sampai usia sepuluh tahun.

3. Sintaksis

Istilah sintaksis diambil dari bahasa Belanda, Syintaxis. Dalam bahasa Inggris digunakan istilah Syintax, yaitu cabang linguistik yang mengkaji seluk beluk kalimat, klausa, dan frase. Sintaksis adalah penguasaan atas suatu bahasa mencakup kemampuan untuk memahami frase 
Alam Budi Kusuma : Pemerolehan Bahasa Pertama

atau kalimat yang bersal dari kata. Sintaksis juga merupakan bagian dari subsistem tata bahasa, sintaksis menelaah struktur satuan bahasa yang lebih besar dari kata mulai dari frase hingga kalimat. 10

Anak-anak mengembangkan tingkat gramatikal kalimat yang dihasilkan melalui beberapa tahap, yaitu melalui peniruan, melalui penggolongan morfem, dan melalui penyusunan dengan cara menempatkan kata-kata secara bersama-sama untuk membentuk kalimat. ${ }^{11}$

4. Semantik

Kata semantik berasal dari bahasa Yunani sema yang berarti kata benda yang berarti tanda atau lambang, kata kerjanya adalah semaino yang berarti menandai atau melambangkan. Yang dimaksud dengan tanda atau lambang disini sebagai padanan kata sema itu adalah tanda linguistic seperti yang dikemukakan Ferdinand de Saussare yaitu yang terdiri dari (1) komponen yang mengartikan, yang berwujud bentuk-bentuk bunyi bahasa, dan (2) komponen yang diartikan atau makna dari komponen yang pertama. Kedua komponen ini adalah merupakan tanda atau lambang; sedangkan yang ditandai atau dilambangi adalah sesuatu yang berada diluar bahasa yang lazim desebut referen atau hal yang ditunjuk. ${ }^{12}$

Istilah linguistik diketahui muncul pada pertengahan abad ke-19. Pada hakikatnya linguistik adalah suatu disiplin

10 Liberty P Sihombing, Pesona bahasa Langkah Awal Memahami Linguistik, (Jakarta: PT Gramedia Pustaka Utama, 2005), hal 123.

11 Teuku Alamsyah, Pemerolehan Bahasa Kedua (Second Language Acqusition). Diktat Kuliah Program S-2. Banda Aceh: Universitas Syiah Kuala, 1997), hal. 21.

12 Abdul Chaer, Pengantar Semantik Bahasa Indonesia, (Jakarta: Rineka Cipta, 2013), hal 2. 
ilmu yang mempelajari bahasa sebagai bagian kebudayaan berdasar struktur bahasa tersebut. ${ }^{13}$ Semantik sendiri bisa diartikan dengan ilmu tentang makna atau arti. ${ }^{14}$ Semantik merupakan bagian dari linguistik. ${ }^{15}$

Anak menggunakan kata-kata tertentu berdasarkan kesamaan gerak, ukuran, dan bentuk. Misalnya, anak sudah mengetahui makna kata jam. Awalnya anak hanya mengacu pada jam tangan orang tuanya, namun kemudian dia memakai kata tersebut untuk semua jenis jam.

\section{E. Teori-teori tentang Pemerolehan Bahasa Pertama}

1. Teori Behaviorisme

Teori adalah seperangkat asas yang tersusun tentang kejadian-kejadian tertentu dalam dunia nyata. Menurut Patrick Suppes ada empat fungsi teori dan berlaku pula untuk teori belajar, ialah (1) berguna sebagai kerangka kerja untuk melakukan penelitian, (2) memberikan suatu kerangka kerja bagi pengorganisasian butir-butir informasi tertentu, (3) mengungkap kekompleksan peristiwa-peristiwa yang terlihat sederhana, dan (4) mengorganisasikan kembali pengalaman-pengalaman sebelumnya. ${ }^{16}$

Kata behaviorisme berasal dari bahasa Inggris yaitu "behavior" artinya tingkah laku, reaksi total. Kemudian diberi akhiran isme menjadi behaviorisme yang berarti aliran dalam psikologi yang obyek penelitiannya adalah sesuatu yang dapat diindra yaitu perilaku yang tampak

13 Jos Daniel Parera, Kajian Linguistik Umum Historis Komparatif dan Tipologi Struktural (Jakarta: PT Gelora Aksara Utama, 1991), hal. 18.

${ }_{14}$ Abdul Chaer, Pengantar Semantik..., hal. 2

15 Sarwiji Suwandi, Semantik, Pengantar Kajian Makna, Yogyakarta: Media Perkasa, 2008), hal.12

16 Margaret E. Bell Gredler, Belajar dan Membelajarkan ( Jakarta: PT Raja Grafindo Persada, 1994), cet ke-2, hal.1-2. 
yang diobservasi. 17 Teori tersebut menekankan pada hubungan antara stimulus dan respon (S-R) yang dapat diamati lewat panca indra dan berpengaruh pada teori belajar bahasa.

Skinner, seperti yang dikutip Barlow dalam bukunya Educational Psychology: The Teaching-Learning Process, berpendapat bahwa belajar adalah suatu proses adaptasi ata penyesuaian tingkah laku yang berlangsung secara progresif. Ia percaya proses tersebut mendatangkan hasil yang optimal apabila diberi penguat (reinforecement) ${ }^{18}$.

Teori behaviorisme menyoroti aspek perilaku kebahasaan yang dapat diamati langsung dan hubungan antara rangsangan (stimulus) dan reaksi (response). Perilaku bahasa yang efektif adalah membuat reaksi yang tepat terhadap rangsangan. Reaksi ini akan menjadi suatu kebiasaan jika reaksi tersebut dibenarkan. Dengan demikian, anak belajar bahasa pertamanya.

Sebagai contoh, seorang anak mengucapkan bilangkali untuk barangkali. Sudah pasti si anak akan dikritik oleh ibunya atau siapa saja yang mendengar kata tersebut. Apabila sutu ketika si anak mengucapkan barangkali dengan tepat, dia tidak mendapat kritikan karena pengucapannya sudah benar. Situasi seperti inilah yang dinamakan membuat reaksi yang tepat terhadap rangsangan dan merupakan hal yang pokok bagi pemerolehan bahasa pertama. hal 118.

17 Agus Sujanto, Psikologi Umum (jakarta: Bumi Aksara, 1993) cet ke-9,

18 Muhibbin Syah, Psikologi Pendidikan dengan Pendekatan Baru, (Bandung: PT Remaja Rosda Karya , 2006), cet ke-12, hal 90. 
B.F. Skinner adalah tokoh aliran behaviorisme. Dia menulis buku Verbal Behavior (1957) yang digunakan sebagai rujukan bagi pengikut aliran ini. Menurut aliran ini, belajar merupakan hasil faktor eksternal yang dikenakan kepada suatu organisme. Menurut Skinner, perilaku kebahasaan sama dengan perilaku yang lain, dikontrol oleh konsekuensinya. Apabila suatu usaha menyenangkan, perilaku itu akan terus dikerjakan. Sebaliknya, apabila tidak menguntungkan, perilaku itu akan ditinggalkan. Singkatnya, apabila ada reinforcement yang cocok, perilaku akan berubah dan inilah yang disebut belajar.

Namun demikian, banyak kritikan terhadap aliran ini. Chomsky mengatakan bahwa toeri yang berlandaskan conditioning dan reinforcement tidak bisa menjelaskan kalimat-kalimat baru yang diucapkan untuk pertama kali dan inilah yang kita kerjakan tiap hari. Bower dan Hilgard juga menentang aliran ini dengan mengatakan bahwa penelitian mutakhir tidak mendukung aliran ini.

Aliran behaviorisme mengatakan bahwa semua ilmu dapat disederhanakan menjadi hubungan stimulusresponse. Hal tersebut tidaklah benar karena tidak semua perilaku berasal dari stimulus-response.

Pendekatan behaviorisme memiliki beberapa pandangan tentang pemerolehan bahasa, diantaranya sebagai berikut:

a. Tabula Rasa, Memandang bahwa anak-anak lahir dengan tabula rasa, sebuah kertas kosong atau sebidang papan tulis bersih tanpa pemahaman tertentu tentang dunia dan bahasa, anak-anak itu kemudian dibentuk 
Alam Budi Kusuma : Pemerolehan Bahasa Pertama

oleh lingkungan mereka dan perlahan-lahan dikondisikan melalui berbagai dorongan terprogram. ${ }^{19}$ Menurut teori ini semua pengetahuan bahasa yang tampak dalam prilaku berbahasa merupakan hasil dari integrasi peristiwa-peristiwa linguistik yang dialami dan diamati oleh manusia tersebut. ${ }^{20}$ Oleh karena itu dapat diketahui bahwa hal dialami dan diamati menunjukan bahwa apa yang tidak dialami dan diamati bukanlah bagian dari pengetahuan linguistik.

b. Perilaku Verbal, teori pengkondisian operan oleh Skinner menyatakan bahwa perilaku berbahasa seseorang sama saja dengan perilaku lainnya terbentuk melalui rangkaian stimulus respon-penguatan, atau dengan kata yang lebih detail, perilaku bahasa seseorang terbentuk oleh serentetan penguatan yang beraneka ragam yang muncul dan dialami oleh orang tersebut. Skinner menyebut aktivitas tersebut dengan istilah perilaku verbal dan bahkan ia menulis buku yang menjelaskan bahasa dalam istilah tersebut. ${ }^{21}$ Teori Skinner tentang perilaku verbal adalah perluasan dari teori operant Conditioning. operant Conditioning adalah pengondisian untuk membuat manusia memberikan tanggapan. Misalnya seorang anak mengatakan " mau susu" dan orang tuanya memberi susu. Menurut Skinner perilaku verbal sama dengan perilaku lainya, dikendalikan oleh konsekuensinya. Bila konsekuensi tersebut berupa imbalan, perilaku itu ditingkatkan kekuatannya. Namun

19 Douglas Brown, Prinsip........ hal. 28.

20 Abdul Chear, Psikolinguistik.......,hal.173

21 Kelvin Seifert, Manajemen Pembelajaran dan Istruksi Pendidikan: Manajemen Mutu Psikologi Pendidikan para Pendidik (Yogyakarta: IRCISOD, 2007), hal. 58 
jika konsekuensinya berupa hukuman atau tidak ada dukungan sama sekali perilaku itu dilemahkan dan pada akhirnya dimatikan. ${ }^{22}$

2. Teori Kognitifisme

Menurut teori ini, bahasa bukanlah suatu ciri alamiah yang terpisah, melainkan salah satu di antara beberapa kemampuan yang berasal dari kematangan kognitif. Bahasa distrukturi oleh nalar. Perkembangan bahasa harus berlandaskan pada perubahan yang lebih mendasar dan lebih umum di dalam kognisi. Jadi, urutanurutan perkembangan kognitif menentukan urutan perkembangan bahasa. ${ }^{23} \mathrm{Hal}$ ini tentu saja berbeda dengan pendapat Chomsky yang menyatakan bahwa mekanisme umum dari perkembangan kognitif tidak dapat menjelaskan struktur bahasa yang kompleks, abstrak, dan khas. Begitu juga dengan lingkungan berbahasa. Bahasa harus diperoleh secara alamiah.

Menurut teori kognitivisme, yang paling utama harus dicapai adalah perkembangan kognitif, barulah pengetahuan dapat keluar dalam bentuk keterampilan berbahasa. Dari lahir sampai 18 bulan, bahasa dianggap belum ada. Anak hanya memahami dunia melalui indranya. Anak hanya mengenal benda yang dilihat secara langsung. Pada akhir usia satu tahun, anak sudah dapat mengerti bahwa benda memiliki sifat permanen sehingga anak mulai menggunakan simbol untuk mempresentasikan benda yang tidak hadir dihadapannya. Simbol ini kemudian berkembang menjadi kata-kata awal yang diucapkan anak.

${ }^{23}$ Abdul Chaer, Psikolinguistik............. (Jakarta: Rineka Cipta, 2003), 


\section{F. Strategi Pemerolehan Bahasa Pertama}

Strategi pertama dalam pemerolehan bahasa dengan berpedoman pada: tirulah apa yang dikatakan orang lain. Tiruan akan digunakan anak terus, meskipun ia sudah dapat sempurna melafalkan bunyi. Ada pendapat yang mengatakan bahwa strategi tiruan atau strategi imitasi ini akan menimbulkan masalah besar. Mungkin ada orang berkata bahwa imitasi adalah mengatakan sesuatu yang sama seperti yang dikatakan orang lain. Akan tetapi ada banyak pertanyaan yang harus dijawab berkenaan dengan hal ini.

Ada berbagai ragam peniruan atau imitasi, yaitu imitasi spontan atau spontaneous imitation, imitasi pemerolehan atau elicited imitation, imitasi segera atau immediate imitation, imitasi terlambat delayed imitation dan imitasi dengan perluasan atau imitation with expansion, reduced imitation.

Strategi kedua dalam pemerolehan bahasa adalah strategi produktivitas. Produktivitas berarti keefektifan dan keefisienan dalam pemerolehan bahasa yang berpegang pada pedoman buatlah sebanyak mungkin dengan bekal yang telah Anda miliki atau Anda peroleh. Produktivitas adalah ciri utama bahasa. Dengan satu kata seorang anak dapat "bercerita atau mengatakan" sebanyak mungkin hal. Kata papa misalnya dapat mengandung berbagai makna bergantung pada situasi dan intonasi.

Strategi ketiga berkaitan dengan hubungan umpan balik antara produksi ujaran dan responsi. Dengan strategi ini anak-anak dihadapkan pada pedoman: hasilkanlah ujaran dan lihatlah bagaimana orang lain memberi responsi. Stategi produktif bersifat "sosial" dalam pengertian bahwa strategi 
tersebut dapat meningkatkan interaksi dengan orang lain dan sementara itu bersifat "kognitif" juga. Hal itu dapat memberikan umpan balik kepada pelajar mengenai ekspresinya sendiri terhadap makna dan juga memberinya sampel yang lebih banyak, yaitu sampel bahasa untuk digarap atau dikerjakan.

Strategi keempat adalah prinsip operasi. Dalam strategi ini anak dikenalkan dengan pedoman: gunakan beberapa “prinsip operasi” umum untuk memikirkan serta menetapkan bahasa. Selain perintah terhadap diri sendiri oleh anak, prinsip operasi ini juga menyarankan larangan yang dinyatakan dalam avoidance terms; misalnya: hindari kekecualian, hindari pengaturan kembali.

\section{G. Proses Pemerolehan Bahasa Kedua}

Pemerolehan bahasa berbeda dengan pembelajaran bahasa. Orang dewasa mempunyai dua cara yang, berbeda berdikari, dan mandiri mengenai pengembangan kompetensi dalam bahasa kedua. Pertama, pemerolehan bahasa merupakan proses yang bersamaan dengan cara anak-anak. Mengembangkan kemampuan dalam bahasa pertama mereka. Pemerolehan bahasa merupakan proses bawah sadar. Para pemeroleh bahasa tidak selalu sadar akan kenyataan bahwa mereka memakai bahasa untuk berkomunikasi.

Kedua, untuk mengembangkan kompetensi dalam bahasa kedua dapat dilakukan dengan belajar bahasa. Anakanak memperoleh bahasa, sedangkan orang dewasa hanya dapat mempelajarinya. Akan tetapi ada hipotesis pemerolehan belajar yang menuntut bahwa orang-orang dewasa juga memperoleh bahasa, kemampuan memungut bahasa bahasa tidaklah hilang pada masa puber. Orang-orang dewasa juga 
dapat memanfaatkan sarana pemerolehan bahasa alamiah yang sama seperti yang dipakai anak-anak. Pemerolehan merupakan suatu proses yang amat kuat pada orang dewasa. Pemerolehan dan pembelajaran dapat dibedakan dalam lima hal, yaitu pemerolehan:

1. memiliki ciri-ciri yang sama dengan pemerolehan bahasa pertama, seorang anak penutur asli, sedangkan belajar bahasa adalah pengetahuan secara formal,

2. secara bawah sadar, sedangkan pembelajaran sadar dan disengaja.

3. bahasa kedua seperti memungut bahasa kedua, sedangkan pembelajaran mengetahui bahasa kedua,

4. mendapat pengetahuan secara implisit, sedangkan pembelajaran mendapat pengetahuan secara eksplisit,

5. pemerolehan tidak membantu kemampuan anak, sedangkan pembelajaran menolong sekali.

Pandangan pemerolehan bahasa secara alami yang merupakan pandangan kaum nativistis yang diwakili oleh Noam Chomsky, berpendapat bahwa bahasa hanya dapat dikuasai oleh manusia. Perilaku bahasa adalah sesuatu yang diturunkan. Hakikatnya, pola perkembangan bahasa pada berbagai macam bahasa dan budaya. Lingkungan hanya memiliki peran kecil dalam pemerolehan bahasa. Anak sudah dibekali apa yang disebut peranti penguasaan bahasa (LAD).

Pandangan pemerolehan bahasa secara disuapi adalah pandangan kaum behavioristis yang diwakili oleh B.F. Skinner dan menganggap bahasa sebagai suatu yang kompleks di antara perilaku-perilaku lain. Kemampuan berbicara dan memahami bahasa diperoleh melalui rangsangan lingkungan. Anak hanya merupakan penerima pasif dari tekanan 
lingkungan. Anak tidak memiliki peran aktif dalam perilaku verbalnya. Perkembangan bahasa ditentukan oleh lamanya latihan yang disodorkan lingkungannya. Anak dapat menguasai bahasanya melalui peniruan. Belajar bahasa dialami anak melalui prinsip pertalian stimulus respon.

Perkembangan bahasa anak adalah suatu kemajuan yang sebarang hingga mencapai kesempurnaan. Pandangan kognitif diwakili oleh Jean Piaget dan berpendapat bahwa bahasa bukan ciri alamiah yang terpisah melainkan satu di antara beberapa kemampuan yang berasal dari pematangan kognitif. Lingkungan tidak besar pengaruhnya terhadap perkembangan intelektual anak. Yang penting adalah interaksi anak dengan lingkungannya.

Cara pemerolehan bahasa kedua dapat dibagi dua cara, yaitu pemerolehan bahasa kedua secara terpimpin dan pemerolehan bahasa kedua secara alamiah. Pemerolehan bahasa kedua yang diajarkan kepada pelajar dengan menyajikan materi yang sudah dipahami. Materi bergantung pada kriteria yang ditentukan oleh guru. Strategi-strategi yang dipakai oleh seorang guru sesuai dengan apa yang dianggap paling cocok bagi siswanya.

Pemerolehan bahasa kedua secara alamiah adalah pemerolehan bahasa kedua/asing yang terjadi dalam komunikasi sehari-hari, bebas dari pengajaran atau pimpinan,guru. Tidak ada keseragaman cara. Setiap individu memperoleh bahasa kedua dengan caranya sendiri-sendiri. Interaksi menuntut komunikasi bahasa dan mendorong pemerolehan bahasa. Dua ciri penting dari pemerolehan bahasa kedua secara alamiah atau interaksi spontan ialah 
Alam Budi Kusuma : Pemerolehan Bahasa Pertama

terjadi dalam komunikasi sehari-hari, dan bebas dari pimpinan sistematis yang sengaja.

\section{H. Kesimpulan}

Pemerolehan bahasa pertama adalah proses penguasaan bahasa pertama oleh anak. Selama penguasaan bahasa pertama ini, terdapat dua proses yang terlibat, yaitu proses kompetensi dan proses performansi. Kedua proses ini tentu saja diperoleh oleh anak secara tidak sadar.

Ada beberapa tahap yang dilalui oleh anak selama memperoleh bahasa pertama. Tahap yang dimaksud adalah tahap pengocehan (babbling), tahap satu-kata atau holofrastis, tahap dua-kata satu frase, tahap ujaran telegrafis. Selain tahap pemerolehan bahsa seperti yang telah disebutkan ini, ada juga para ahli bahasa, seperti Aitchison mengemukakan beberapa tahap pemerolehan bahasa anak.

Tahap-tahap yang dia maksud adalah mendengkur, meraban, pola intonasi, tuturan satu kata, tuturan dua kata, infleksi kata, bentuk tanya dan bentuk ingkar, konstruksi yang jarang atau kompleks, tuturan yang matang. Meskipun terjadi perbedaan dalam hal pembagian tahap-tahap yang dilalui oleh anak saat memperoleh bahasa pertamanya, jika dilihat secara cermat, pembahasan dalam setiap tahap pemerolehan bahasa pertama anak memiliki kesamaan, yaitu adanya proses fonologi, morfologi, sintaksis, semantik, pragmatik.

Bagaimana sebenarnya proses pemerolehan bahasa pertama ini? Ada beberapa teori pemerolehan bahasa yang menjelaskan hal ini, yaitu teori behaviorisme, nativisme, kognitivisme, interaksionisme. Keempat teori ini memiliki 
Alam Budi Kusuma : Pemerolehan Bahasa Pertama

sudut pandang yang berbeda dalam menjelaskan perihal cara anak memperoleh bahasa pertamanya. 


\section{DAFTAR PUSTAKA}

Agus Sujanto. 1993. Psikologi Umum. Jakarta: Bumi Aksara

Alamsyah, Teuku. 1997. Pemerolehan Bahasa Kedua (Second Language Acqusition). Diktat Kuliah Program S-2. Banda Aceh: Universitas Syiah Kuala.

Brown, Douglas 2007. Prinsip Pembelajaran dan Pengajaran bahasa (Jakarta: Kedubes Amerika Serikat.

Chaer, Abdul. 2003. Psikolinguistik:Kajian Teoretik. Jakarta: Rineka Cipta.

. 1990. Pengantar Semantik Bahasa Indonesia. Jakarta: Rineka Cipta.

Dardjowidjojo, Soenjono. Psikolinguistik: Pengantar Pemahaman Bahasa Manusia. Jakarta: Yayasan Obor.

Fromkin Victoria dan Robert Rodman. 1993. An Introduction to Language. Florida: Harcourt Brace Jovanovich Collage.

Iskandarwassid dkk. 2008.Strategi Pembelajaran Bahasa Asing (Bandung: PT Remaja Rosdakarya.

Mar'at, Samsunuwiyati. 2005. Psikolinguistik Suatu Pengantar. Bandung: PT Refika Aditama.

Margaret E. Bell Gredler. 1994. Belajar dan Membelajarkan. Jakarta: PT Raja Grafindo Persada.

Parera, Jos Daniel. 1991. Kajian Linguistik Umum Historis Komparatif dan Tipologi Struktural. Jakarta: PT Gelora Aksara Utama.

Syah, Muhibbin. 2006. Psikologi Pendidikan dan Pendekatan Baru. Bandung: Remaja Rosda Karya.

Seifert, Kelvin. 2007. Manajemen Pembelajaran dan Istruksi Pendidikan: Manajemen Mutu Psikologi Pendidikan para Pendidik. Yogyakarta: IRCISOD. 
Alam Budi Kusuma : Pemerolehan Bahasa Pertama

Sihombing, Liberty P. 2005. Pesona bahasa Langkah Awal Memahami Linguistik. Jakarta: PT Gramedia Pustaka Utama.

Suwandi, Sarwiji. 2008. Semantik, Pengantar Kajian Makna. Yogyakarta: Media Perkasa. 